\title{
Technical Note: One year of Raman-lidar measurements in Gual Pahari EUCAARI site close to New Delhi in India - Seasonal characteristics of the aerosol vertical structure
}

\author{
M. Komppula ${ }^{1}$, T. Mielonen ${ }^{1}$, A. Arola ${ }^{1}$, K. Korhonen ${ }^{1}$, H. Lihavainen ${ }^{2}$, A.-P. Hyvärinen ${ }^{2}$, H. Baars ${ }^{3}$, R. Engelmann ${ }^{3}$, \\ D. Althausen ${ }^{3}$, A. Ansmann ${ }^{3}$, D. Müller ${ }^{3,4, *}$, T. S. Panwar ${ }^{5}$, R. K. Hooda ${ }^{2,5}$, V. P. Sharma ${ }^{5}$, V.-M. Kerminen ${ }^{2,6}$, \\ K. E. J. Lehtinen ${ }^{1,7}$, and Y. Viisanen ${ }^{2}$ \\ ${ }^{1}$ Finnish Meteorological Institute, 70211 Kuopio, Finland \\ ${ }^{2}$ Finnish Meteorological Institute, 00101 Helsinki, Finland \\ ${ }^{3}$ Leibniz Institute for Tropospheric Research, 04318 Leipzig, Germany \\ ${ }^{4}$ Atmospheric Remote Sensing Laboratory, Gwangju Institute of Science and Technology, Buk-Gu Gwangju 500-712, \\ Republic of Korea \\ ${ }^{5}$ The Energy and Resource Institute, Dabari Seth Block, IHC Complex, Lodhi Road, 110003 New Delhi, India \\ ${ }^{6}$ Department of Physics, P.O. Box 64, University of Helsinki, 00014 Helsinki, Finland \\ ${ }^{7}$ Department of Applied Physics, University of Eastern Finland, 70211 Kuopio, Finland \\ *now at: Science Systems and Applications, Inc., MS 475 NASA Langley Research Center, Hampton, VA, 23681, USA
}

Correspondence to: M. Komppula (mika.komppula@fmi.fi)

Received: 6 September 2010 - Published in Atmos. Chem. Phys. Discuss.: 22 December 2010

Revised: 27 April 2012 - Accepted: 27 April 2012 - Published: 24 May 2012

\begin{abstract}
One year of multi-wavelength (3 backscatter +2 extinction +1 depolarization) Raman lidar measurements at Gual Pahari, close to New Delhi, were analysed. The data was split into four seasons: spring (March-May), summer (June-August), autumn (September-November) and winter (December-February). The vertical profiles of backscatter, extinction, and lidar ratio and their variability during each season are presented. The measurements revealed that, on average, the aerosol layer was at its highest in spring $(5.5 \mathrm{~km})$. In summer, the vertically averaged (between 1$3 \mathrm{~km}$ ) backscatter and extinction coefficients had the highest averages $\left(3.3 \mathrm{Mm}^{-1} \mathrm{sr}^{-1}\right.$ and $142 \mathrm{Mm}^{-1}$ at $532 \mathrm{~nm}$, respectively). Aerosol concentrations were slightly higher in summer compared to other seasons, and particles were larger in size. The autumn showed the highest lidar ratio and high extinction-related Ångström exponents $\left(\mathrm{AE}_{\mathrm{ext}}\right)$, indicating the presence of smaller probably absorbing particles. The winter had the lowest backscatter and extinction coefficients, but $\mathrm{AE}_{\mathrm{ext}}$ was the highest, suggesting still a large amount of small particles.
\end{abstract}

\section{Introduction}

The influences of atmospheric aerosols on climate, including their direct radiative effects and various indirect effects related to aerosol-cloud interactions, have large uncertainties (e.g. Ramanathan et al., 2001a; Lohmann and Feichter, 2005; Quaas et al., 2008; Schwartz et al., 2010). The climatic effects of aerosol particles depend on their chemical, physical and optical properties, along with their vertical distribution. Advanced lidar systems, which can determine the optical properties of aerosols in a quantitative way and enable the estimation of the main microphysical properties, can provide ground-truth information for the retrieval of aerosol products from space-borne instruments.

In Southern Asia, only few measurements of aerosol vertical profiles have been carried out, and most of the available data is from short field campaigns. However, observations in this polluted area are crucial to reveal information of the local air quality and climate change, as they are exposed to substantial quantities of particulate air pollution (e.g. Lelieveld et al., 2001; Nakajima et al., 2007; Ramanathan et al., 2007a). The largest and most persistent of

Published by Copernicus Publications on behalf of the European Geosciences Union. 
these pollution hazes, called the "brown cloud", covers an area of about 10 million $\mathrm{km}^{2}$ over Southern Asia and concerns more than $50 \%$ of the world's population. This particulate air pollution is assumed to originate from fossil fuel and biomass burning (e.g. Ramanathan et al., 2001b). The polluted air is likely to have significant harmful effects on human health and regional climate over Southern Asia (e.g. Pandey et al., 2005; Lau and Kim, 2006a; Ramanathan et al., 2007b). The proposed "elevated heat pump" effect suggests that atmospheric heating by absorbing aerosols (dust and black carbon), through water cycle feedbacks, may lead to a strengthening of the South Asian monsoon (Lau et al., 2006b; Lau et al., 2008). Elevated aerosol layers, especially during the pre-monsoon season, are likely to have larger radiative impacts when located above clouds (Satheesh et al., 2008). Overall, it has been suggested that the atmospheric brown cloud in Asia contributes to the regional lower-tropospheric warming as much as the recent increase of the anthropogenic greenhouse gases (Ramanathan et al., 2007b).

In a few measurement campaigns, aerosol vertical profiles have been determined over the oceanic regions adjacent to India, such as the Arabian Sea, tropical Indian Ocean and Bay of Bengal. The Indian Ocean Experiment (INDOEX) employed aircraft aerosol profiling and measurements of aerosol profiles from island-based and ship-borne lidars (Müller et al., 2001a, b; Welton et al., 2002; Pelon et al., 2002). Vertical distribution of aerosol particles over the continental India have been measured in few studies only, including those carried out over the south central India (Moorthy et al., 2004; Gadhavi and Jayaraman, 2006). Long-term measurements are even sparser, even though continuous measurements of aerosol vertical distribution have been made at Visakhapatnam and Kharagpur (Niranjan et al., 2006, 2007a, b). Devara et al. (2008) used a mobile lidar in Pune, India, whereas Badarinath et al. (2009) measured backscatter coefficient profiles $(532 \mathrm{~nm})$ for different conditions at Hyderabad in October 2007. Ganguly et al. (2006a) investigated physical and optical aerosol properties over Ahmedabad for the time period of many years, providing seasonal-average data for the pre-monsoon (AprilMay), monsoon (June-September), post-monsoon (OctoberNovember) and dry seasons (December-February). For the measurement of aerosol optical properties, they used a sun photometer, aethalometer, nephelometer and a lidar.

A network of seven portable micro pulse lidar systems was established (Hegde et al. 2009). None of these instruments is close to the megacity of New Delhi. To our knowledge, however, no other such campaigns have been carried in this region. In the current paper, we will present an overview of a one-year-long measurement campaign on aerosol vertical profiles close to New Delhi. The measurements are based on a multi-wavelength Raman lidar which, among other things, provides information on the vertical distribution of aerosol absorption not measured before in this region. The central aims of this work are to estimate the seasonal variation of vertical aerosol properties and to give some information on aerosol sources. This paper provides also a useful data set for further use in model applications and satellite validation.

\section{Methods}

\subsection{Site description}

We established a one-year-long campaign of Raman lidar measurements to investigate aerosol vertical profiles in Gual Pahari ( $28^{\circ} 26^{\prime} \mathrm{N}, 77^{\circ} 09^{\prime} \mathrm{E}, 243 \mathrm{~m}$ a.s.l.), India (Fig. 1). The station is located about $20 \mathrm{~km}$ south of New Delhi, representing a semi-urban environment surrounded mainly by agricultural test fields and light vegetation. The station is located in an area where only electric-powered vehicles are allowed. There are no major local pollution sources, except the road between Gurgaon and Faridabad about $0.5 \mathrm{~km}$ to the southwest of the station. Anthropogenic sources in the region include traffic, city emissions and power production (Reddy and Venkataraman, 2002a, b). The lidar measurements were conducted between March 2008 and March 2009. The measurements belong to the frame of the EUCAARI (European Integrated project on Aerosol Cloud Climate and Air Quality interactions) project (Kulmala et al., 2009, 2011). During the EUCAARI project four one-year lidar campaigns were conducted outside Europe. The particular locations were near New Delhi in India, near Manaus in Brazil, $150 \mathrm{~km}$ away from Beijing in China and in South Africa, about $150 \mathrm{~km}$ east from Johannesburg (Kulmala et al., 2009, 2011). This paper concentrates on the results from the Indian campaign at the Gual Pahari site.

The Gual Pahari station had also a comprehensive set of ground-level aerosol measurements (Hyvärinen et al., 2010). These measurements included Twin-Differential Mobility Particle Sizer (DMPS, particle number size distribution over the diameter range 4-850 nm, total particle number concentration), Aerosol Particle Sizer (APS, particle number size distribution over the diameter range $0.5-10 \mu \mathrm{m}$ ), Multiangle Absorption Photometer (MAAP, aerosol black carbon concentration, absorption coefficient at $670 \mathrm{~nm}$ ) and Nephelometer (aerosol scattering coefficient at $520 \mathrm{~nm}$ ). In addition, the measurement setup included, partly overlapping the lidar measurement period, a Cimel sun photometer for columnar aerosol optical depth (AOD) measurements and the Partisol filter sampler for measurements of aerosol mass, $\mathrm{EC} / \mathrm{OC}$ fraction and inorganic chemistry.

Moreover, ambient temperature, relative humidity, rain intensity, wind direction and wind speed were measured. The average temperatures were at their highest during the summer $\left(28.1^{\circ} \mathrm{C}\right)$, but the maximum temperature was found during the spring season $\left(42.5^{\circ} \mathrm{C}\right)$. This was due to much higher diurnal temperature gradient during the spring. During the winter, the coldest nights reached zero degrees Celsius. (Hyvärinen et al., 2010). 


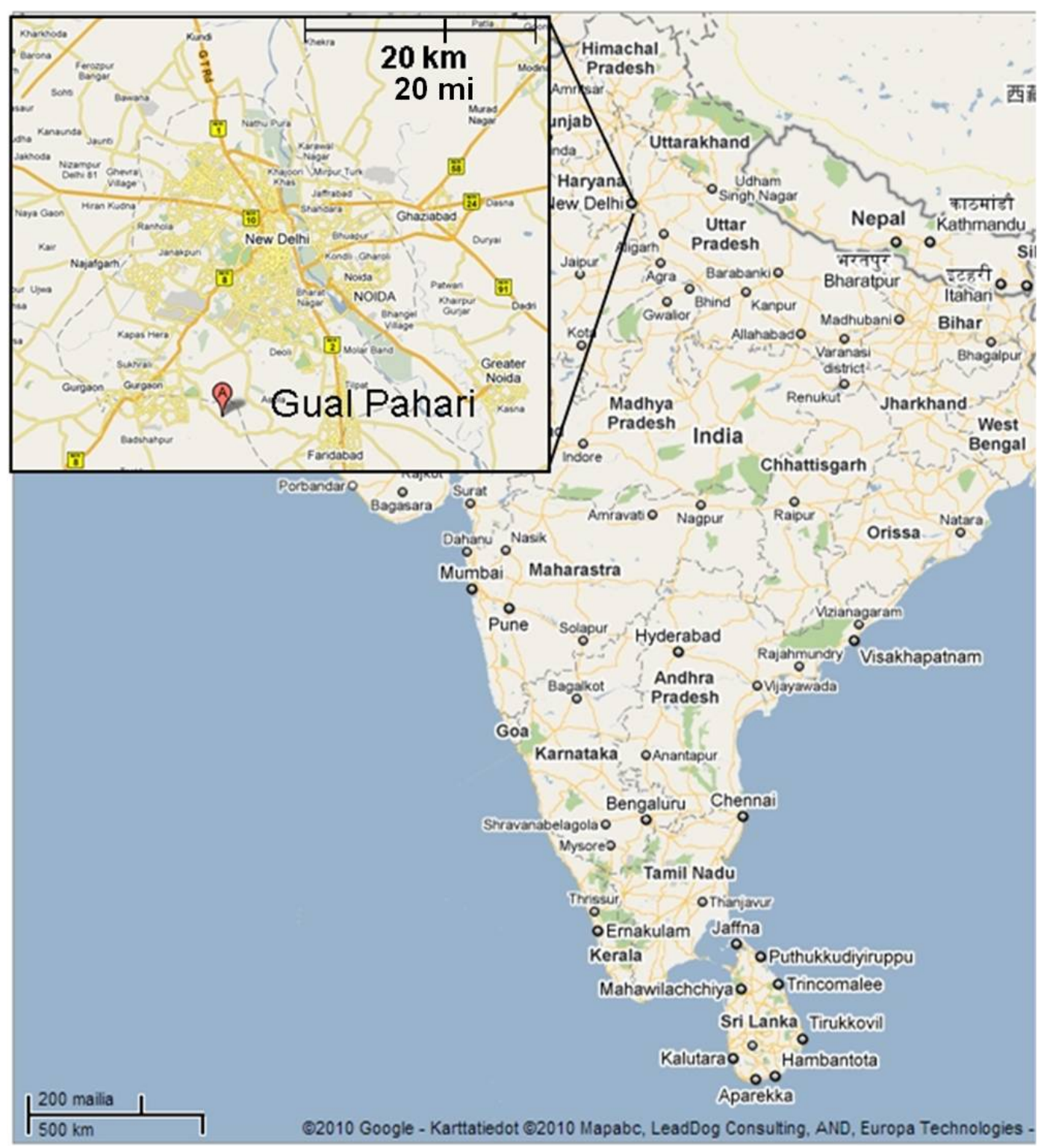

Fig. 1. Location of the Gual Pahari measurement station.

The trajectory analysis for the 950-hPa level showed a mixed air mass patterns during spring, having contributions from a wide western sector between NW and SW (i.e. Arabian Sea). During the summer, the main contribution was from the W-SW sector with a small fraction of air masses coming from the E-SE sector. The autumn and winter had similar air mass patterns, mainly from the NW sector. The autumn had a small contribution from the E-SE sector. Overall, the sectors from $\mathrm{N}$ to NE and from SE to SW contributed very little to the incoming air masses. This illustrates that air transported over the central New Delhi does not seem to play an important overall role at the station. (Hyvärinen et al., 2010).

\subsection{The lidar instrument}

The measurements were conducted with a seven-channel Raman lidar called "POLLYXT_POrtabLe Lidar sYstem eXTended" (Althausen et al., 2009). The lidar system is completely remotely controlled, and all the measurements and data transfer are performed automatically. The instrument is equipped with an uninterruptible power supply (UPS) and an air conditioning system (A/C) to allow for safe and smooth continuous measurements. A rain sensor is connected to the roof cover in order to assure a proper shutdown of the instrument during rain. When the sensor detects rain, a signal is sent to the data acquisition software which in turn shuts down the laser and ends the measurement. In addition to 


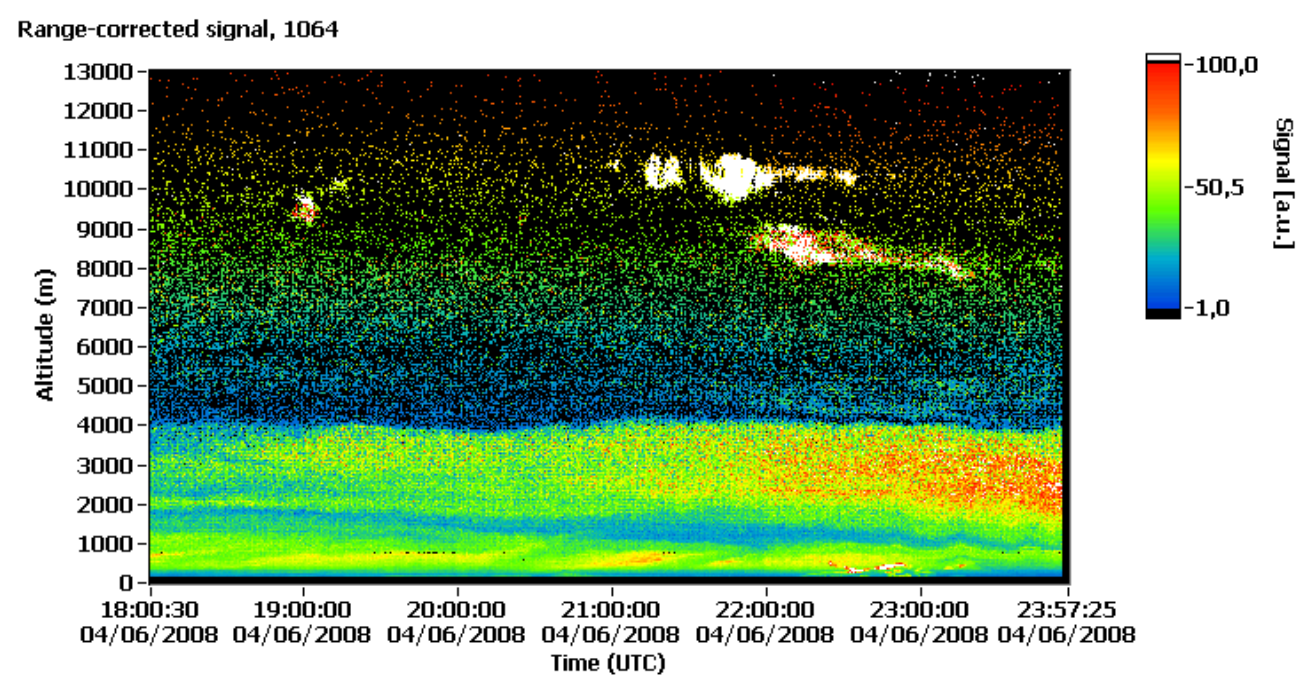

Fig. 2. An example backscatter time series at $1064 \mathrm{~nm}$ wavelength in Gual Pahari on 4 June 2008.

these, the system is equipped with airplane radar that shuts down the laser in case an airplane is detected. The radar is constructed by following the main guidelines presented by Duck et al. (2005).

The type of the laser used is Inlite III from Continuum. It emits energy simultaneously approximately $180 \mathrm{~mJ}, 110 \mathrm{~mJ}$, and $60 \mathrm{~mJ}$ at $1064 \mathrm{~nm}, 532 \mathrm{~nm}$, and $355 \mathrm{~nm}$, respectively. The emitted radiation is linearly polarized at $355 \mathrm{~nm}$. A beam expander is used to enlarge the beam from approximately $6 \mathrm{~mm}$ to about $45 \mathrm{~mm}$ before it enters the atmosphere. The backscattered signal is collected by a Newtonian telescope which has a main mirror with a diameter of $300 \mathrm{~mm}$ and a focal length of $900 \mathrm{~mm}$. The receiver's field of view is $1 \mathrm{mrad}$.

The output of the instrument includes vertical profiles of the particle backscattering coefficient at three wavelengths $(355,532$ and $1064 \mathrm{~nm})$ and of the particle extinction coefficient at two wavelengths ( 355 and $532 \mathrm{~nm}$ ). The extinction coefficient is retrieved with the Raman method by using the in-elastic backscattering from the nitrogen molecules (at $387 \mathrm{~nm}$ and $607 \mathrm{~nm}$ ). The vertically-integrated extinction coefficient gives the AOD. The nighttime profiles are determined using the Raman lidar method (Ansmann et al., 1990) and for the daytime profiles Fernald-Klett method (Fernald, 1984; Klett, 1981) is used. Detailed description and steps of the determination of the parameters for Polly ${ }^{\mathrm{XT}}$ lidars is found in Althausen et al., 2009. In addition, such size/composition-dependent, intensive particle quantities as the extinction-to-backscatter ratio, commonly known as lidar ratio, the Ångström exponents (AE) for backscatter and extinction and depolarisation can be determined. The lidar ratio gives indication of particle properties and origin by giving the ratio of the extinction and backscatter coefficients. When having the lidar ratio at two wavelengths, some indication of particle size is retrieved. In addition, the Angström exponent provides information on the particle size. It is de- fined between two wavelengths and calculated with a formula: $\mathrm{AE}=\log \left(I_{\lambda 1, h} / I_{\lambda 2, h}\right) /\left(\lambda_{1} / \lambda_{2}\right)$, where $\lambda_{1}$ and $\lambda_{2}$ are the wavelengths, $I_{\lambda i, h}$ is the backscatter or extinction coefficient on wavelength $\lambda_{i}$ at certain height $h$. The depolarisation channel $(355 \mathrm{~nm})$ of the lidar enables us to separate spherical particles from non-spherical and hence ice-containing clouds from water clouds.

Finally, the height and the evolution of the boundary layer top and night-time residual layer can be defined from the lidar data, along with the height and thickness of different cloud and aerosol layers. The vertical resolution of the system is $30 \mathrm{~m}$. Depending on the cloudiness, the whole troposphere can be monitored.

\subsection{Data evaluation}

The lidar measurements were carried out continuously. During the one-year-long measurement period, Polly ${ }^{\mathrm{XT}}$ was measuring on 183 days for almost $2500 \mathrm{~h}$ in total. From these measurements, we calculated close to 500 one-hour average profiles (Table 1). Our aim was to calculate an averaged profile over every three hours. However, this requirement was limited by rain, low level clouds/fog and technical issues. In addition, during some of the nights the aerosol layer was too thin and close to the surface to be detected reliably. Only cases without low clouds are considered in this analysis.

The data were split into four seasons: spring (MarchMay), summer (June-August), autumn (SeptemberNovember) and winter (December-February). Also values for the official rainy season (16 June-19 September) were calculated, but they were left out from the results section as they did not differ from the values presented here for summer due to almost the same time interval. Figure 2 shows an example of a six-hour-long time series of lidar measurements at the $1064 \mathrm{~nm}$ wavelength. A complex 
aerosol structure can be seen, with multiple aerosol layers up to $4 \mathrm{~km}$, some high-level clouds at $8-11 \mathrm{~km}$, and also some waves near the ground.

Due to technical problems with the laser, the data coverage from September to January is sparse. Measurements could not be done in October 2008 and January 2009, and in September and November-December only a few usable profiles were measured (Table 1).

Each backscatter profile was determined using the method by Althausen et al. (2009). The radiosonde data supplied by the Department of Atmospheric Science at University of Wyoming were used to account for the molecular backscattering. In case of night-time measurements, also extinction and lidar ratio profiles were determined. Seasonal backscatter, extinction and lidar ratio profiles were averaged from the one-hour profiles. The automatically retrived backscatter plots are available at http://polly.tropos.de/lidar/. The averaged one-hour profiles for backscatter and extinction profiles are available at EUCAARI database. The more detailed data requests can be addressed to the authors.

\section{Results and discussion}

\subsection{Aerosol backscattering}

The aerosol backscatter coefficients at $355 \mathrm{~nm}, 532 \mathrm{~nm}$ and $1064 \mathrm{~nm}$ wavelengths are presented in Fig. 3. The profiles showed a clear seasonal variation. The summer had the largest mean backscatter coefficient averaged between the 1 and 3-km height, while the winter had the lowest one (Table 2). The seasonal-average value for summer at $355 \mathrm{~nm}$ was $5.0 \mathrm{Mm}^{-1} \mathrm{sr}^{-1}$, the profile reaching maximum values of $8 \mathrm{Mm}^{-1} \mathrm{sr}^{-1}$ at around the $1-\mathrm{km}$ height.

The seasonal profiles of backscattering coefficients had distinctly different shapes. In summer, the values of these coefficients had the steepest decrease from 1 to $3 \mathrm{~km}$. The autumn, and especially the winter, had a relatively shallow aerosol layer that touched the ground. The value of the backscatter coefficient was highest near the ground and then it decreased moderately with increasing altitude. The ground-based measurements at the site show higher particle mass concentrations in winter, which is in line with the lidar results (Hyvärinen et al., 2010).

Considering the following figures from this point on (Figs. 3-8), the thick lines in the figures represent the seasonal average profile averaged from all single profiles available for that particular season. The numbers of profiles are indicated in the title of each subplot. The horizontal bars represent the standard deviation among this set of single profiles, which shows the variation within the season. Thus they should not be misinterpreted as error bars of the calculated mean.

Badarinath et al. (2009) reported backscatter coefficients at $532 \mathrm{~nm}$ for a normal day and for a day with a high aerosol loading at Hyderabad in October 2007. For the normal day the backscattering coefficient was $6 \mathrm{Mm}^{-1} \mathrm{sr}^{-1}$ near the surface, while for the polluted day it was as high as $13 \mathrm{Mm}^{-1} \mathrm{sr}^{-1}$. The normal-day value is a bit higher than what we see in our results as the mean of the season but still it fits well within the standard deviation of all the single profiles of our measurements. The polluted case fits well in the values observed in Gual Pahari, as the maximum values for different seasons observed at $532 \mathrm{~nm}$ were around $15-25 \mathrm{Mm}^{-1} \mathrm{sr}^{-1}$.

The average thickness of the aerosol layer showed a clear seasonal behaviour as well (Fig. 3; Table 2). The aerosol layer thickness ("the top of the layer") was determined at the point where backscatter coefficient values get below $0.1 \mathrm{Mm}^{-1} \mathrm{sr}^{-1}$. On average, the highest aerosol layers were observed during spring $(5500 \mathrm{~m})$ and the lowest ones during winter $(4310 \mathrm{~m})$. The structure of the vertical distribution was often multi-layered and reached up to few kilometres. A number of studies (e.g. Ansmann et al., 2000; Müller et al., 2001a, b; Welton et al., 2002; Franke et al., 2003; Niranjan et al., 2006, 2007b; Pelon et al., 2002; Satheesh et al., 2009) have reported that aerosol plumes in India can rise up to the height of $3-5 \mathrm{~km}$. Some of these studies note also the multi-layered aerosol structure. Our seasonal averages confirm these results. Throughout the year, the aerosol layers rose up close to $5 \mathrm{~km}$ or even higher, as can be seen from Table 2. Niranjan et al. (2006) reported measurements on thick surface aerosol layers (up to 1.5-2 km) in December 2004 over Kharagpur, India. This behaviour is also observed in our winter season data.

\subsection{Aerosol extinction}

The aerosol extinction coefficients at $355 \mathrm{~nm}$ and $532 \mathrm{~nm}$ were determined for dark hours only (with the Raman method). The main seasonal variation of these coefficients followed similar patterns as those of the backscatter cofficients (Figs. 3 and 4). The summer had the highest extinction coefficients, and the autumn and winter had the lowest ones (Table 2). The seasonal-average value of the extinction coefficient at $355 \mathrm{~nm}$ between 1 and $3 \mathrm{~km}$ was $174 \mathrm{Mm}^{-1}$ during the summer, the profile reaching values of $300 \mathrm{Mm}^{-1} \mathrm{sr}^{-1}$ at maximum (Fig. 4). The summer had a more moderate decrease of the extinction coefficient with altitude than the other seasons. The winter had a relatively shallow, optically thick aerosol layer touching the ground, with a high extinction coefficient near the ground and then a relatively steep decrease in its value with an increasing altitude. The low and thick aerosol layer is supported by the ground-based measurements, showing the highest $\mathrm{BC}$ concentrations in winter (Hyvärinen et al., 2010).

Ganguly et al. (2006a) studied the variability of physical and optical aerosol properties over Ahmedabad for several years. They calculated seasonal averages for the pre-monsoon (April-May), monsoon (JuneSeptember), post-monsoon (October-November), and dry 
Table 1. The amount of one-hour backscatter and extinction profiles for each month from March 2008 to March 2009.

\begin{tabular}{lllllllllllllll}
\hline & Mar & Apr & May & Jun & Jul & Aug & Sep & Oct & Nov & Dec & Jan & Feb & Mar & Tot \\
\hline bsc & 31 & 47 & 37 & 56 & 61 & 41 & 12 & - & 6 & 6 & - & 66 & 103 & 466 \\
ext & 21 & 21 & 20 & 17 & 22 & 27 & 6 & - & 5 & 5 & - & 45 & 55 & 244 \\
\hline
\end{tabular}

Table 2. Summary of the seasonal particle properties at Gual Pahari. Given values for backscatter, extinction, lidar ratio and Ångström exponents are mean values of the season at $1-3 \mathrm{~km}$ altitude and 10 and 90 percentiles at the same height.

\begin{tabular}{llllll}
\hline & Spring (Mar-May) & Summer (Jun-Aug) & Autumn (Sep-Nov) & Winter (Dec-Feb) & Annual \\
\hline $\operatorname{bsc}_{355}\left(\mathrm{Mm}^{-1} \mathrm{sr}^{-1}\right)$ & $3.1(0.8 / 5.8)$ & $5.0(0.8 / 9.9)$ & $2.9(0.1 / 5.9)$ & $1.7(0.1 / 3.9)$ & $3.6(0.5 / 8.0)$ \\
$\operatorname{bsc}_{532}\left(\mathrm{Mm}^{-1} \mathrm{sr}^{-1}\right)$ & $2.1(0.5 / 4.3)$ & $3.3(0.5 / 7.1)$ & $1.2(0.0 / 2.3)$ & $1.2(0.1 / 2.9)$ & $2.4(0.3 / 5.6)$ \\
$\operatorname{bsc}_{1064}\left(\mathrm{Mm}^{-1} \mathrm{sr}^{-1}\right)$ & $1.3(0.3 / 2.7)$ & $1.4(0.1 / 3.3)$ & $0.8(0.0 / 1.6)$ & $0.7(0.0 / 1.7)$ & $1.2(0.1 / 2.9)$ \\
$\operatorname{ext}_{355}\left(\mathrm{Mm}^{-1}\right)$ & $133(43 / 245)$ & $174(27 / 351)$ & $80(28 / 133)$ & $122(24 / 212)$ & $154(42 / 310)$ \\
$\operatorname{ext}_{532}\left(\mathrm{Mm}^{-1}\right)$ & $94(22 / 195)$ & $142(14 / 321)$ & $68(19 / 134)$ & $76(0 / 149)$ & $123(24 / 283)$ \\
$\mathrm{LR}_{355}(\mathrm{sr})$ & $45(27 / 61)$ & $57(28 / 92)$ & $77(51 / 103)$ & $46(22 / 67)$ & $50(28 / 77)$ \\
$\mathrm{LR}_{532}(\mathrm{sr})$ & $36(16 / 55)$ & $53(23 / 87)$ & $60(28 / 93)$ & $37(14 / 57)$ & $42(18 / 68)$ \\
$\mathrm{AE}_{\text {bsc 355/532 }}$ & $0.92(0.24 / 1.65)$ & $1.02(0.08 / 2.05)$ & $0.99(0.02 / 1.79)$ & $0.83(0.01 / 1.91)$ & $0.95(0.07 / 1.94)$ \\
$\mathrm{AE}_{\text {bsc } 532 / 1064}$ & $0.85(0.14 / 1.77)$ & $1.42(0.48 / 2.35)$ & $1.03(0.05 / 2.01)$ & $0.85(0.14 / 1.53)$ & $1.11(0.21 / 2.18)$ \\
$\mathrm{AE}_{\text {bsc 355/1064 }}$ & $0.87(0.43 / 1.58)$ & $1.39(0.61 / 2.24)$ & $1.12(0.37 / 2.16)$ & $0.92(0.32 / 1.58)$ & $1.11(0.46 / 1.99)$ \\
$\mathrm{AE}_{\text {ext 355/532 }}$ & $1.14(0.11 / 2.12)$ & $0.71(0.01 / 1.63)$ & $1.31(0.31 / 2.30)$ & $1.43(0.43 / 2.19)$ & $1.05(0.01 / 2.13)$ \\
$\mathrm{Layer} \mathrm{thickness}^{*}(\mathrm{~m})$ & $5500(3150 / 6100)$ & $4560(2370 / 4960)$ & $4860(1300 / 5220)$ & $4310(1560 / 4740)$ & $4960(2120 / 5500)$
\end{tabular}

* The layer thickness (the layer top) is determined at the point where bsc values get below $0.1 \mathrm{Mm}^{-1} \mathrm{sr}^{-1}$.
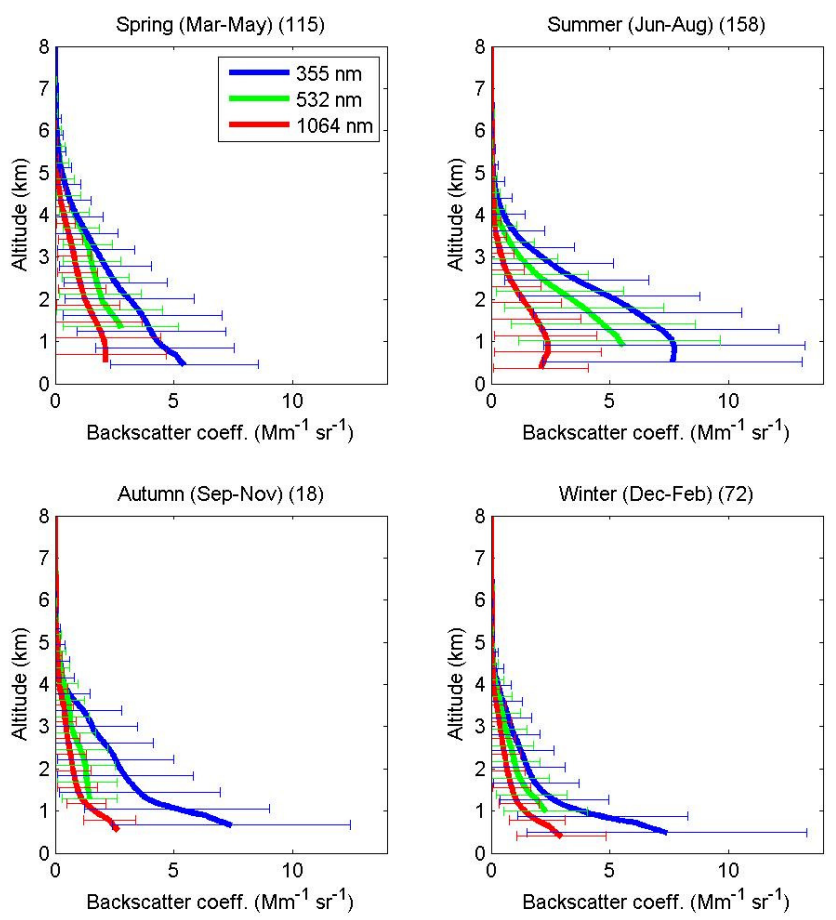

Fig. 3. Seasonal averaged backscatter profiles at three wavelengths with standard deviations for the Gual Pahari site. The value in the plot title indicates the number of profiles used in calculations for each season.
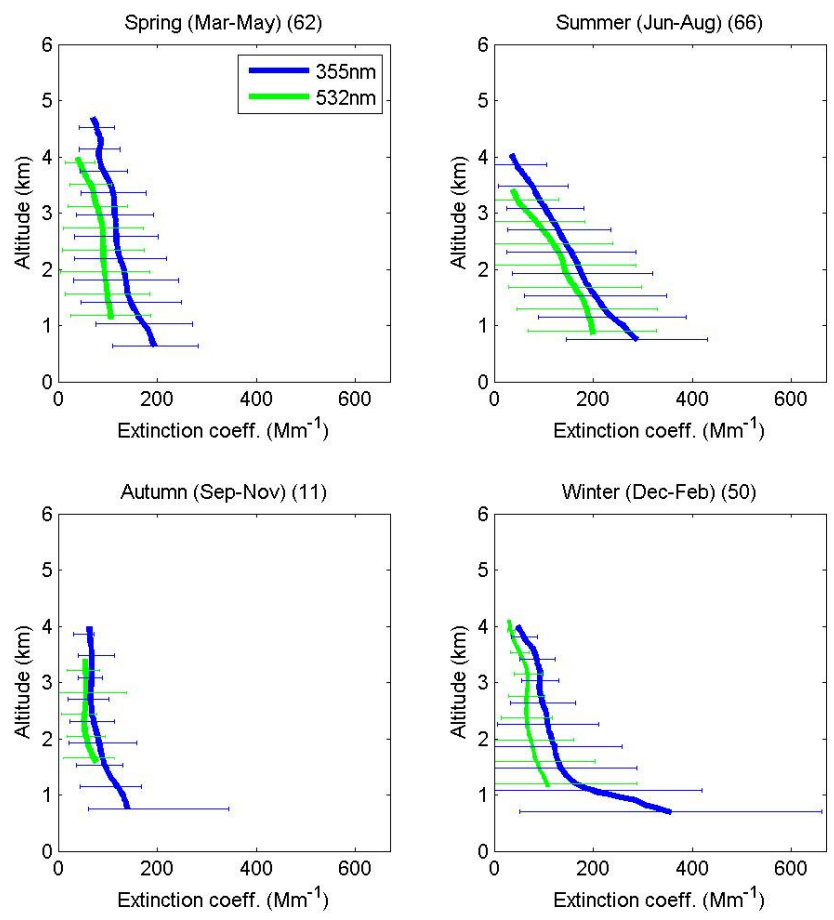

Fig. 4. Seasonal averaged extinction profiles at two wavelengths with standard deviations for the Gual Pahari site. The value in the plot title indicates the number of profiles used in calculations for each season. 

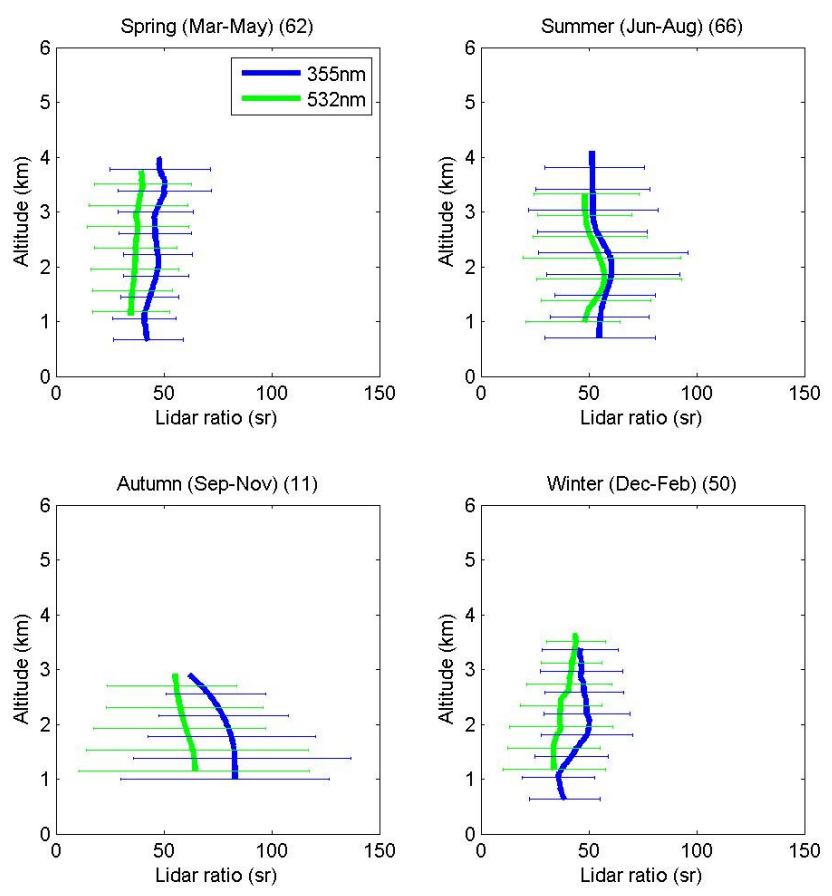

Fig. 5. Seasonal averaged lidar ratio profiles for $355 \mathrm{~nm}$ (blue) and $532 \mathrm{~nm}$ (green) with standard deviations. The value in the plot title indicates the number of profiles used in calculations for each season.

seasons (December-February). Although these seasons are not exactly the same as our spring, summer, autumn and winter, they are close enough for a rough comparison. The overall behaviour of the seasonal variation was found to be comparable between the study of Ganguly et al. (2006a) and that of ours. When comparing the spring and pre-monsoon extinction profiles at $532 \mathrm{~nm}$, our profile (Fig. 4) is a bit steeper. The summer (monsoon), autumn (post-moon) and winter (dry season) profiles agree quite well, as do the range of the extinction values.

Ganguly et al. (2006a, b) observed further that in the dry (December-February) and post-monsoon (OctoberNovember) seasons, the profiles were characterized by high values of extinction coefficients within the first few hundred meters from the surface followed by sharp decreases in these values with an increasing altitude. This is well in line with our winter extinction profile in Fig. 4. Such a behavior in the winter, and partly in the autumn, is explained mainly by the meteorological situation. In winter, the surface-based inversion layer is at low altitudes and has a weaker development of the boundary layer compared to other seasons.

Welton et al. (2002) measured polluted air masses on a ship at Indian Ocean and retrieved extinction values of up to $2000 \mathrm{Mm}^{-1}$. The maximum extinction coefficients observed in our measurements in Gual Pahari were of the same order, being $1500-2000 \mathrm{Mm}^{-1}$. Franke et al. (2003) conducted measurements over Maldives in February 1999 and March 2000. They observed extinction coefficient at $532 \mathrm{~nm}$ that

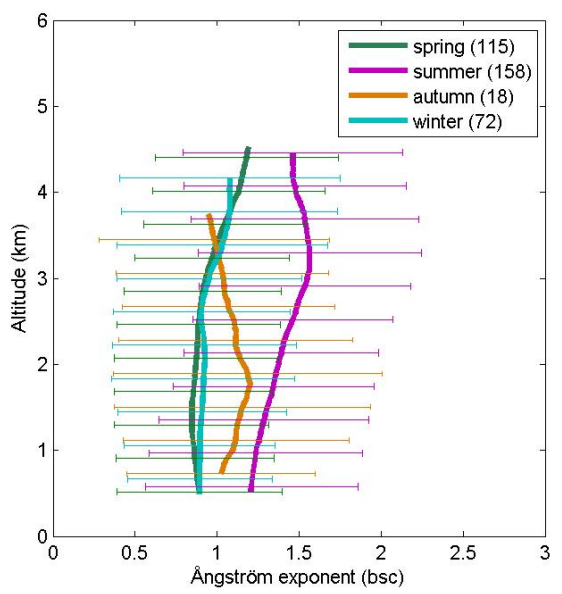

Fig. 6. Seasonal averaged Ångström exponent for backscatter $\left(\mathrm{AE}_{\mathrm{bsc}} 355-1064\right)$ with standard deviations. The value in the legend indicates the number of profiles used in calculations.

ranged typically between 25 and $175 \mathrm{Mm}^{-1}$ in elevated pollution layers originating from the Indian continent. This is in the range of our observations.

\subsection{Lidar ratio}

The lidar ratio, i.e. the ratio between extinction and backscatter coefficients, can be presented at $355 \mathrm{~nm}$ and $532 \mathrm{~nm}$. The lidar ratio gives the possibility to estimate the properties and origin of the measured aerosol particles. The ratio was calculated for all the pairs of backscatter and extinction profiles available. Due to the only-night-time extinction profiles, these results are presented for the dark hours only.

The seasonal averages of the lidar ratios at $355 \mathrm{~nm}$ varied from $45 \mathrm{sr}$ in the spring to $77 \mathrm{sr}$ in the autumn, and the corresponding variability at $532 \mathrm{~nm}$ was from 36 to $60 \mathrm{sr}$ (Table 2; Fig. 5). The lidar ratios at $532 \mathrm{~nm}$ were below $40 \mathrm{sr}$ in the spring and winter, indicating the presence of a cleaner air mass with relatively more aged aerosols as during the other seasons. In the winter though, the aerosol layer was thin and strong near ground, as seen in the extinction profiles. During the summer and autumn, the average lidar ratios were larger than $50 \mathrm{sr}$, suggesting the presence/dominance of absorbing aerosols from biomass burning.

Müller et al. (2001a, b) reported lidar ratios $(532 \mathrm{~nm})$ for different aerosol types measured at Maldives. Well-aged polluted air had lidar ratios of 40-45 sr, while fresher anthropogenic pollution had lidar ratios of $60 \mathrm{sr}$ and $45-75 \mathrm{sr}$. Clean continental air were detected with a lidar ratio of $45 \mathrm{sr}$, and clean marine/continental air were linked with lidar ratios of 20-30 sr and 35-55 sr. Welton et al. (2002) made also lidar measurement at Maldives. They measured lidar ratios of $33 \pm 6 \mathrm{sr}$ for a clean marine air, whereas polluted marine air had lidar ratios well above $40 \mathrm{sr}$. In addition, Pelon et al. (2002) measured lidar ratios of 67, 71, and 


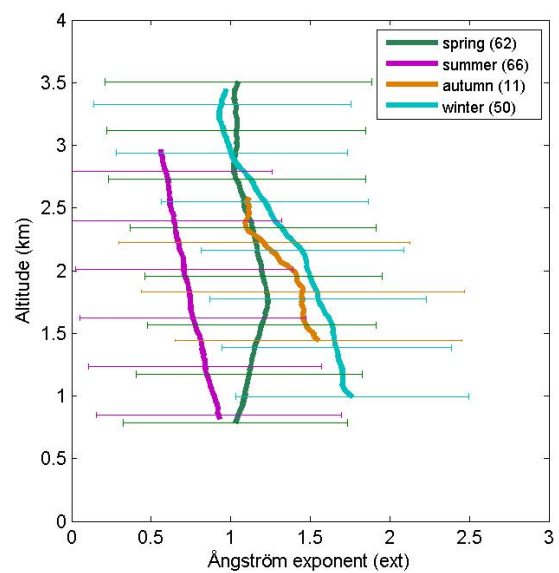

Fig. 7. Seasonal averaged Ångström exponent for extinction ( $\left.\mathrm{AE}_{\text {ext }} 355-532\right)$ with standard deviations. The value in the legend indicates the number of profiles used in calculations.

$83 \mathrm{sr}$ for pollution plumes originating from India. Franke et al. (2003) analysed pollution plumes originating from India. They found lidar ratios of 50-80 sr for highly-absorbing particles coming from northern India. Our seasonally-averaged lidar ratio values between 36 and $60 \mathrm{sr}$ at $532 \mathrm{~nm}$ are in good agreement with previous measurements (Table 2).

\section{4 Ångström exponents}

The Ångström exponents (AE) were calculated from the backscatter for three wavelength combinations $(355-532 \mathrm{~nm}$, $532-1064 \mathrm{~nm}$ and $355-1064 \mathrm{~nm}$ ) (Table 2; $\mathrm{AE}_{\mathrm{bsc}} 355-1064$ shown in Fig. 6), as well as from the extinction $(355-532 \mathrm{~nm})$ (Fig. 7). $\mathrm{AE}_{\text {ext }}$ refers to particle size: the larger the exponent, the smaller the particles and vice versa. $\mathrm{AE}_{\mathrm{bsc}}$, if used next to the complex refractive index, depends also on particle size. The AE values for the autumn give only some hint of the real value due to the low amount of data points. Overall, the scattering $\mathrm{AE}\left(\mathrm{AE}_{\mathrm{bsc}}\right)$ showed higher values during the summer $\left(\mathrm{AE}_{\mathrm{bsc}} 355-1064=1.39\right)$ and lower values in the spring and winter $\left(\mathrm{AE}_{\mathrm{bsc}} 355-1064=0.87\right.$ and 0.92) (Table 2; Fig. 6). The autumn values for $\mathrm{AE}_{\mathrm{bsc}} 355-1064$ were in between these values.

The extinction related $\mathrm{AE}_{\text {ext355-532 }}$ was found to be the highest in the winter (1.43) and autumn, and the lowest in the summer (0.71) (Table 2; Fig. 7). This suggests that aerosol particles were larger in size in the summer and smaller in the winter/autumn. This makes sense, since there is more biomass burning for heating and cooking in the winter to produce smaller absorbing aerosols, and is also in line with the AE results by Ganguly et al. (2006a, b) who also observed dominance of smaller particles during the winter and autumn months. Hyvärinen et al. (2010) reported a decrease in smaller size fractions during the summer (rainy season), which is in agreement of the low $\mathrm{AE}_{\text {ext }}$ value in our summer data.
Dey and Di Girolamo (2010) made an extensive climatology of aerosol properties over India from Multiangle Imaging Spectroradiometer (MISR) data. Their averaged AE values for the winter $(1.13 \pm 0.09)$ and pre-monsoon season $(1.00 \pm 0.13)$ in Central India are slightly lower than our $\mathrm{AE}_{\text {ext }} 355-532$ values of 1.43 and 1.14, respectively. For the summer (monsoon, $1.08 \pm 0.11$ ), our $\mathrm{AE}_{\text {ext }} 355-532$ value of 0.71 is slightly lower. The autumn (post-monsoon) values have large uncertainties, but there are a fairly good agreement between our study (1.31) and that by Dey and Di Girolamo (2010) (1.21 \pm 0.09$)$. Our AE values are also in the same range than those presented by Niranjan et al. $(2007 \mathrm{a}, \mathrm{b})$ and Franke et al. (2003).

Singh et al. (2010) reported the yearly variation of $\mathrm{AE}_{\mathrm{ext}}$ in Delhi to be between 0.38 and 0.96 . These values are bit smaller than our seasonal averages (0.71-1.43). They also reported the annual $\mathrm{AE}_{\text {ext }}$ average of $0.68 \pm 0.35$ in Delhi during 2006. This value is also slightly smaller than our annualaverage value of 1.05 .

\subsection{Annual averages}

The annual-average profiles for backscatter (bsc), extinction (ext), lidar ratio and AE values are presented in Fig. 8. The values are averages for the whole measurement period, excluding March 2009. The bsc $_{355}$ reached values of up to $7 \mathrm{Mm}^{-1} \mathrm{sr}^{-1}$ and ext 355 reached values of up to $300 \mathrm{Mm}^{-1}$. The annual-average of lidar ratio was $50 \mathrm{sr}$ at $355 \mathrm{~nm}$ is and $42 \mathrm{sr}$ at $532 \mathrm{~nm}$. The $\mathrm{AE}_{\mathrm{bsc}}$ had an annual average in the range of $0.95-1.11$, depending slightly on the wavelength combination. $\mathrm{AE}_{\mathrm{ext}}$ had an annual average value of 1.05.

\subsection{Comparison to other locations}

The published annual/seasonal datasets of continuous multiwavelength lidar measurements are still sparse. Here we compare the obtained results to three other locations at different regions to give a feeling of scale of our results. The other locations are Thessaloniki in Greece, Kühlungsborn in Germany and Seoul/Gosan in Republic of Korea. Our annual backscatter values $(355,532$ and $1064 \mathrm{~nm})$ near New Delhi were about the double compared to values by Schneider et al. (2002) measured in Northern Germany. The south European backscatter ( 355 and $532 \mathrm{~nm})$ and extinction $(355 \mathrm{~nm})$ values measured in Thessaloniki (Amaridis et al., 2005; Giannakaki et al., 2010) were at about the same level as our values. Southern Europe is frequently affected by Saharan dust outflows which are the main factor causing the elevated values in Thessaloniki as in India the main sources are the local and regional biomass and fossil fuel burning. The seasonal extinction profiles obtained by Kim et al. (2007) in the Republic of Korea showed about $50 \%$ smaller values depending on the season. Spring values were closest to the values in India due to the Asian dust storms elevating the values. 

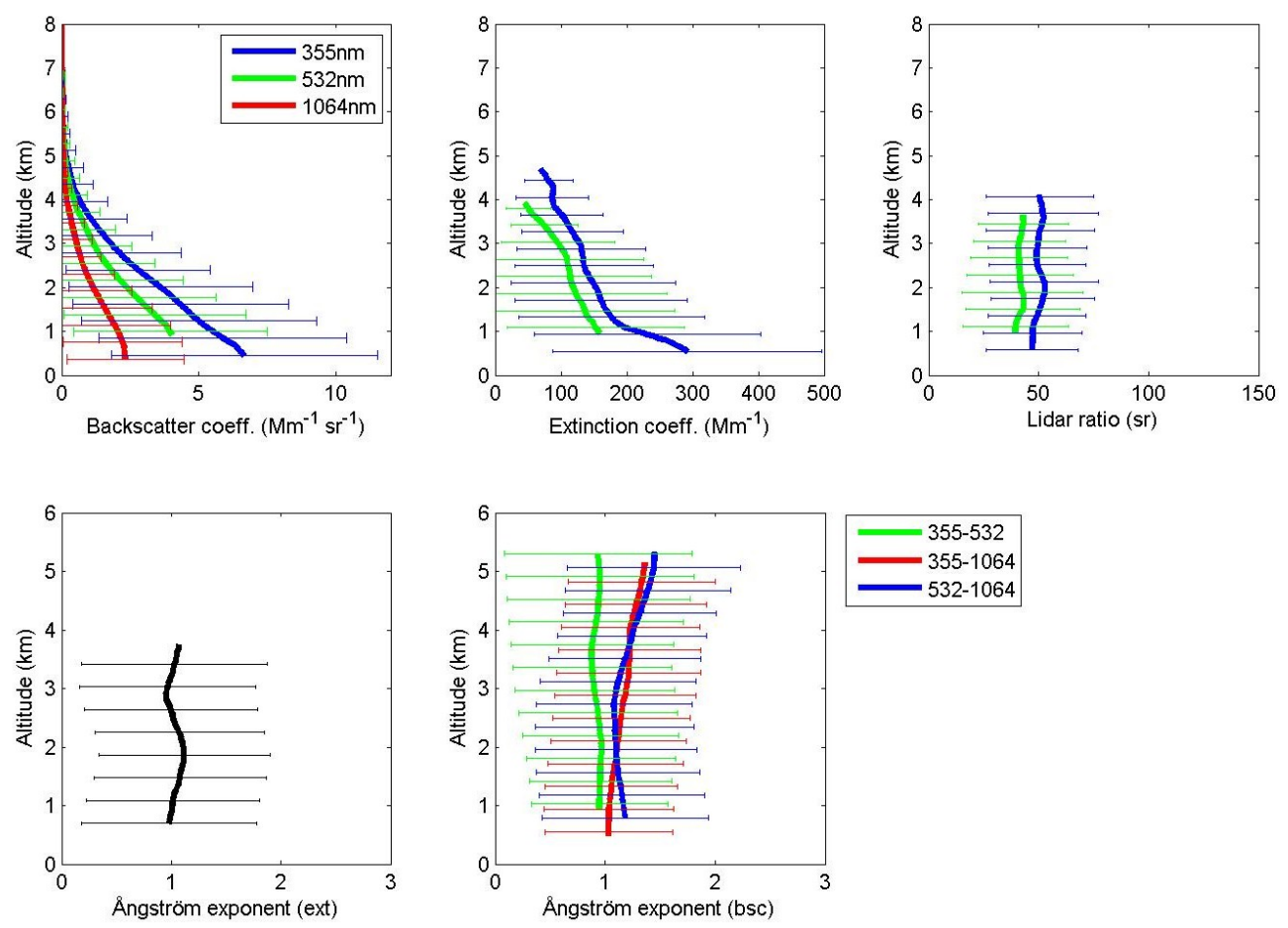

Fig. 8. Averages over the one-year measurement period for backscatter, extinction, lidar ratio and Ångström exponents with standard deviations.

Overall, the aerosol loads obtained in Gual Pahari, near New Delhi are at the higher end of published values.

\section{Summary and conclusions}

One year of multi-wavelength Raman lidar measurements were analysed. The data were split into four seasons, and the seasonal averages were presented for spring (March-May), summer (June-August), autumn (September-November) and winter (December-February). A summary of seasonal parameters and statistics can be found in Table 2. The autumn had only a few data profiles, and especially the AEs must be interpreted carefully.

Overall, our results are in agreement with most of the measurements made in India and southern Asia. The summer showed the highest values of backscatter and extinction coefficients, when averaged over the $1-3 \mathrm{~km}$ height. In the summer, measured air masses were slightly more polluted and particles were a bit larger than in other seasons. It has to be remembered that the lidar is not measuring during rain, summer being the rainy season. The lidar ratios had their highest values in the autumn and summer, which refers to more absorbing particles. The backscatter-related AE values reached their highest values in the summer and autumn. The extinction-related $\mathrm{AE}$ values reached their highest values in the autumn and winter, indicating that the particles were smaller. The combination of autumn showing the high- est lidar ratio and high $\mathrm{AE}_{\text {ext }}$ refers to smaller probably absorbing particles. The winter had the lowest backscatter and extinction coefficients, but the highest $\mathrm{AE}_{\text {ext }}$, suggesting still a large amount of small particles. The aerosol layer thickness followed mainly the seasonal pattern of the temperature. The highest values were observed in spring when the heating of ground, and thus convective mixing, was at its strongest. The lowest values in the winter can also be explained by the meteorology.

Generally the results show a distinct seasonal pattern of aerosol profiles, mainly driven by the seasonal meteorology (i.e. different mixing of the boundary layer). The near-ground $(\sim 1 \mathrm{~km})$ values are at about same level on average for all seasons, but the aerosol layer top level varies between the seasons. The seasonal aerosol backscatter and extinction coefficients obtained in Gual Pahari, near New Delhi are at the higher end of the published values.

Acknowledgements. This work is funded by the The European Integrated project on Aerosol Cloud Climate and Air Quality Interactions, EUCAARI. Timo Anttila is acknowledged for technical assistance and staff at TERI's Gual Pahari Retreat for valuable assistance and routine monitoring of the lidar.

Edited by: U. Pöschl 


\section{References}

Althausen, D., Engelmann, R., Baars, H., Heese, B., Ansmann, A., Müller, D., and Komppula, M.: Portable Raman Lidar Polly(XT) for Automated Profiling of Aerosol Backscatter, Extinction, and Depolarization, J. Atmos. Ocean. Technol., 26, 2366-2378, 2009.

Amaridis, V., Balis, D. S., Kazadis, S., Bais, A., and Giannakaki, E.: Four-year aerosol observations with a Raman lidar at Thessaloniki, Greece, in the framework of European Aerosol Research Lidar Network (EARLINET), J. Geophys. Res., 110, D21203, doi:10.1029/2005JD006190, 2005.

Ansmann, A., Riebesell, M., and Weitkamp, C.: Measurements of atmospheric aerosol extinction profiles with a Raman lidar, Opt. Lett., 15, 746-748, 1990.

Ansmann, A., Althausen, D., Wandinger, U., Franke, K., Müller, D., Wagner, F., and Heintzenberg, J.: Vertical profiling of the Indian aerosol plume with six-wavelength lidar during INDOEX: A first case study, Geophys. Res. Lett., 27, 963-966, 2000.

Badarinath, K. V. S., Kharol, S. K., and Sharma, A. R.: Long-range transport of aerosols from agriculture crop residue burning in Indo-Gangetic Plains-A study using LIDAR, ground measurements and satellite data, J. Atmos. Solar-Terr. Phys., 71, 112 120, ISSN 1364-6826, doi:10.1016/j.jastp.2008.09.035, 2009.

Devara, P. C. S., Raj, P. E., Dani, K. K., Pandithurai, G., Kalapureddy, M. C. R., Sonbawne, S. M., Rao, Y. J., and Saha, S. K.: Mobile Lidar Profiling of Tropical Aerosols and Clouds, J. Atmos. Ocean. Technol., 25, 1288-1295, 2008.

Dey, S. and Di Girolamo, L.: A climatology of aerosol optical and microphysical properties over the Indian subcontinent from 9 years (2000-2008) of Multiangle Imaging Spectroradiometer (MISR) data, J. Geophys. Res., 115, D15204, doi:10.1029/2009JD013395, 2010.

Duck, T. J, Firanski, B., Lind, F. D., and Sipler D.: Aircraftprotection radar for use with atmospheric lidars, Appl. Opt., 44, 4937-4945, 2005.

Fernald, F. G.: Analysis of atmospheric lidar observations: Some comments, Appl. Opt., 23, 652-653, 1984.

Franke, K., Ansmann, A., Müller, D., Althausen, D., Venkataraman, C., Reddy, M. S., Wagner, F., and Scheele, R.: Optical properties of the Indo-Asian haze layer over the tropical Indian Ocean, J. Geophys. Res., 108, 4059, doi:10.1029/2002JD002473, 2003.

Gadhavi, H. and Jayaraman, A.: Airborne lidar study of the vertical distribution of aerosols over Hyderabad, an urban site in central India, and its implication for radiative forcing calculations, Ann. Geophys., 24, 2461-2470, 2006, http://www.ann-geophys.net/24/2461/2006/.

Ganguly, D., Jayaraman, A., and Gadhavi, H.: Physical and optical properties of aerosols over an urban location in western India: Seasonal variabilities, J. Geophys. Res., 111, D24206, doi:10.1029/2006JD007392, 2006a.

Ganguly, D., Jayaraman, A., Rajesh, T. A., and Gadhavi, H.: Wintertime aerosol properties during foggy and nonfoggy days over urban center Delhi and their implications for shortwave radiative forcing, J. Geophys. Res., 111, D15217, doi:10.1029/2005JD007029, 2006b.

Giannakaki, E., Balis, D. S., Amaridis, V., and Zerefos, C.: Optical properties of different aerosol types: seven years of combined Raman-elastic backscatter lidar measurements in Thessaloniki, Greece, Atmos. Meas. Tech., 3, 569-578, doi:10.5194/amt-3-
569-2010, 2010.

Hegde, P., Pant, P., and Kumar Y. B.: An integrated analysis of lidar observations in association with optical properties of aerosols from a high altitude location in central Himalayas, Atmos. Sci. Lett., 10, 48-57, 2009.

Hyvärinen, A.-P., Lihavainen, H., Komppula, M., Panwar, T. S., Sharma, V. P., Hooda, R. K., and Viisanen, Y.: Aerosol measurements at the Gual Pahari EUCAARI station: preliminary results from in-situ measurements, Atmos. Chem. Phys., 10, 72417252, doi:10.5194/acp-10-7241-2010, 2010.

Kim, S.-W., Yoon, S.-C., Kim, J., and Kim, S.-W.: Seasonal and monthly variations of columnar aerosol optical properties over east Asia determined from multi-year MODIS, LIDAR, and AERONET Sun/sky radiometer measurements, Atmos. Environ., 41, 1634-1651, 2007.

Klett, J. D.: Stable analytical inversion solution for processing lidar returns, Appl. Opt., 20, 211-220, 1981.

Kulmala, M., Asmi, A., Lappalainen, H. K., Carslaw, K. S., Pöschl, U., Baltensperger, U., Hov, Ø., Brenquier, J.-L., Pandis, S. N., Facchini, M. C., Hansson, H.-C., Wiedensohler, A., and O'Dowd, C. D.: Introduction: European Integrated Project on Aerosol Cloud Climate and Air Quality interactions (EUCAARI) - integrating aerosol research from nano to global scales, Atmos. Chem. Phys., 9, 2825-2841, doi:10.5194/acp-9-2825-2009, 2009.

Kulmala, M., Asmi, A., Lappalainen, H. K., Baltensperger, U., Brenguier, J.-L., Facchini, M. C., Hansson, H.-C., Hov, Ø., O’Dowd, C. D., Pöschl, U., Wiedensohler, A., Boers, R., Boucher, O., de Leeuw, G., Denier van den Gon, H., Feichter, J., Krejci, R., Laj, P., Lihavainen, H., Lohmann, U., McFiggans, G., Mentel, T., Pilinis, C., Riipinen, I., Schulz, M., Stohl, A., Swietlicki, E., Vignati, E., Amann, M., Ammann, M., Alves, C., Arabas, S., Artaxo, P., Beddows, D. C. S., Bergström, R., Beukes, J. P., Bilde, M., Burkhart, J. F., Canonaco, F., Clegg, S., Coe, H., Crumeyrolle, S., D’Anna, B., Decesari, S., Gilardoni, S., Fischer, M., Fjæraa, A. M., Fountoukis, C., George, C., Gomes, L., Halloran, P., Hamburger, T., Harrison, R. M., Herrmann, H., Hoffmann, T., Hoose, C., Hu, M., Horrak, U., Iinuma, Y., Iversen, T., Josipovic, M., Kanakidou, M., Kiendler-Scharr, A., Kirkevag, A., Kiss, G., Klimont, Z., Kolmonen, P., Komppula, M., Kristjansson, J.-E., Laakso, L., Laaksonen, A., Labonnote, L., Lanz, V., Lehtinen, K. E. J., Makkonen, R., McMeeking, G., Merikanto, J., Minikin, A., Mirme, S., Morgan, W. T., Nemitz, E., O’Donnell, D., Panwar, T. S., Pawlowska, H., Petzold, A., Pienaar, J. J., Pio, C., Plass-Duelmer, C., Prevot, A. S. H., Pryor, S., Reddington, C. L., Roberts, G., Rosenfeld, D., Schwarz, J., Seland, Ø., Sellegri, K., Shen, X. J., Siebert, H., Sierau, B., Simpson, D., Sun, J. Y., Topping, D., Tunved, P., Vaattovaara, P., Vakkari, V., Veefkind, J. P., Visschedijk, A., Vuollekoski, H., Vuolo, R., Wehner, B., Wildt, J., Woodward, S., Worsnop, D. R., van Zadelhoff, G.-J., Zardini, A. A., Zhang, K., van Zyl, P. G., Kerminen, V.-M., Carslaw, K. S., and Pandis, S. N.: General overview: European Integrated project on Aerosol Cloud Climate and Air Quality interactions (EUCAARI) - integrating aerosol research from nano to global scales, Atmos. Chem. Phys., 11, 13061-13143, doi:10.5194/acp-11-13061-2011, 2011.

Lau, K.-M. and Kim, K.-M.: Observational relationships between aerosol and Asian monsoon rainfall, and circulation, Geophys. Res. Lett., 33, L21810, doi:10.1029/2006GL027546, 2006 a. 
Lau, K. M., Kim, M. K., and Kim, K. M.: Asian summer monsoon anomalies induced by aerosol direct forcing: the role of the Tibetan Plateau, Clim. Dynam., 26, 855-864, doi:10.1007/s00382006-0114-z, 2006b.

Lau, K. M., Ramanathan, V., Wu, G.-X., Li, Z., Tsay, C., Hsu, C., Sikka, R., Holben, B., Lu, D., Tartari, G., Chin, M., Koudelova, P., Chen, H., Ma, Y., Huang, J., Taniguchi, K., and Zhang, R.: The joint aerosol-monsoon experiment: A New Challenge for Monsoon Climate Research, B. Am. Meteor. Soc., 85, 1491-1501, 2008.

Lohmann, U., and Feichter J.: Global indirect aerosol effects: a review, Atmos. Chem. Phys., 5, 715-737, doi:10.5194/acp-5-7152005, 2005.

Lelieveld, J., Crutzen, P. J., Ramanathan, V., Andreae, M. O., Brenninkmeijer, C. A. M., Campos, T., Cass, G. R., Dickerson, R. R., Fischer, H., de Gouw, J. A., Hansel, A.,, Jefferson, A., Kley, D., de Laat, A. T. J., Lal, S., Lawrence, M. G., Lobert, J. M., MayolBracero, O. L., Mitra, A. P., Novakov, T., Oltmans, S. J., Prather, K. A., Reiner, T., Rodhe, H., Scheeren, H. A., Sikka, D., and Williams, J.: The Indian Ocean Experiment: Widespread air pollution from South and Southeast Asia, Science, 291, 1031-1036, 2001.

Moorthy, K. K., Babu, S. S., Sunilkumar, S. V., Gupta, P. K., and Gera, B. S.: Altitude profiles of aerosol BC, derived from aircraft measurements over an inland urban location in India, Geophys. Res. Lett., 31, L22103, doi:10.1029/2004GL021336, 2004.

Müller, D., Franke, K., Wagner, F., Althausen, D., Ansmann, A., and Heintzenberg, J.: Vertical profiling of optical and physical particle properties over the tropical Indian Ocean with six-wavelength lidar 1. Seasonal cycle, J. Geophys. Res., 106, 28567-28575, 2001a.

Müller, D., Franke, K., Wagner, F., Althausen, D., Ansmann, A., Heintzenberg, J., and Verver, G.: Vertical profiling of optical and physical particle properties over the tropical Indian Ocean with six-wavelength lidar 2. Case studies, J. Geophys. Res., 106, 28577-28595, 2001b.

Nakajima, T., Yoon, S.-C., Ramanathan, V., Shi, G.-Y., Takemura, T., Aoki, K., Sohn, B.-J., Kim, S.-W., Tsuruta, H., Sugimoto, N., Shimizu, A., Tanimoto, H., Sawa, Y., Lin, N.-H., Lee, C.T., Goto, D., and Schutgens, N.: Overview of the Atmospheric Brown Cloud East Asian Regional Experiment 2005 and a study of the aerosol direct radiative forcing in East Asia, J. Geophys. Res., 112, D24S91, doi:10.1029/2007JD009009, 2007.

Niranjan, K., Sreekanth, V., Madhavan, B. L., and Krishna Moorthy, K.: Wintertime aerosol characteristics at a north Indian site Kharagpur in the Indo-Gangetic plains located at the outflow region into Bay of Bengal, J. Geophys. Res., 111, D24209, doi:10.1029/2006JD007635, 2006.

Niranjan, K., Sreekanth, V., Madhavan, B. L., and Krishna Moorthy, K.: Aerosol physical properties and Radiative forcing at the outflow region from the Indo-Gangetic plains during typical clear and hazy periods of wintertime, Geophys. Res. Lett., 34, L19805, doi:10.1029/2007GL031224, 2007a.

Niranjan, K., Madhavan, B. L., and Sreekanth, V.: Micro pulse lidar observation of high altitude aerosol layers at Visakhapatnam located on the east coast of India, Geophys. Res. Lett., 34, L03815, doi:10.1029/2006GL028199, 2007b.

Pandey, J. S., Kumar, R., and Devotta, S.: Health risks of NO2, SPM and SO2 in Delhi (India), Atmos. Environ., 39, 6868-6874, 2005.
Pelon, J., Flamant, C., Chazette, P., Leon, J.-F., Tanre, D., Sicard, M., Satheesh, S. K.: Characterization of aerosol spatial distribution and optical properties over the Indian Ocean from airborne LIDAR and radiometry during INDOEX'99, J. Geophys. Res., 107, 8029, doi:10.1029/2001JD000402, 2002.

Quaas, J., Boucher, O., Bellouin, N., and Kinne, S.: Satellite-based estimate of the direct and indirect aerosol climate forcing, J. Geophys. Res., 113, D05204, doi:10.1029/2007JD008962, 2008.

Ramanathan, V., Crutzen, P. J., Kiehl, J. T., and Rosenfeld, D.: Atmosphere - Aerosols, climate, and the hydrological cycle, Science, 294, 2119-2124, 2001a.

Ramanathan, V., Crutzen, P. J., Lelieveld, J., Mitra, A. P., Althausen, D., Andersons, J., Andreae, M. O., Cantrell, W., Cass, G. R., Chung, C. E., Clarke, A. D., Coakley, J. A., Collins, W. D., Conant, W. C., Dulac, F., Heintzenberg, J., Heymsfield, A. J., Holben, B., Howell, S., Hudson, J., Jayaraman, A., Kiehl, J. T., Krishnamurti, T. N., Lubin, D., McFarquhar, G., Novakov, T., Ogren, J. A., Podgorny, I. A., Prather, K., Priestley, K., Prospero, J. M., Quinn, P. K., Rajeev, K., Rasch, P., Rupert, S., Sadourny, R., Satheesh, S. K., Shaw, G. E., Sheridan, P., and Valero, F. P. J.: Indian Ocean Experiment: An integrated analysis of the climate forcing and effects of the great Indo-Asian haze, J. Geophys. Res., 106, 28371-28398, 2001 b.

Ramanathan, V., Li, F., Ramana, M. V., Praveen, P. S., Kim, D., Corrigan, C. E., Nguyen, H., Stone, E. A., Schauer, J. J., Carmichael, G. R., Adhikary, B., and Yoon, S. C.: Atmospheric brown clouds: Hemispherical and regional variations in long-range transport, absorption and radiative forcing, J. Geophys. Res., 112, D22S21, doi:10.1029/2006JD008124, 2007a.

Ramanathan, V., Ramana, M. V., Roberts, G., Kim, D., Corrigan, C., Chung, C., and Winker, D.: Warming trends in Asia amplified by brown cloud solar absorption, Nature, 448, 575-579, $2007 \mathrm{~b}$.

Reddy, M. S. and Venkataraman, C.: Inventory of aerosol and sulphur dioxide emissions from India: I-Fossil fuel combustion, Atmos. Environ., 36, 677-697, 2002a.

Reddy, M. S. and Venkataraman, C.: Inventory of aerosol and sulphur dioxide emissions from India. Part II-biomass combustion, Atmos. Env., 36, 699-712, $2002 b$.

Satheesh, S. K., Krishna Moorthy, K., Suresh Babu, S., Vinoj, V., and Dutt, C. B. S.: Climate implications of large warming by elevated aerosol over India, Geophys. Res. Lett., 35, L19809, doi:10.1029/2008GL034944, 2008.

Satheesh, S. K., Vinoj, V., Suresh Babu, S., Krishna Moorthy, K., and Nair Vijayakumar S.: Vertical distribution of aerosols over the east coast of India inferred from airborne LIDAR measurements, Ann. Geophys., 27, 4157-4169, doi:10.5194/angeo-274157-2009, 2009.

Singh, S., Soni, K., Bano, T., Tanwar, R. S., Nath, S., and Arya, B. C.: Clear-sky direct aerosol radiative forcing variations over mega-city Delhi, Ann. Geophys., 28, 1157-1166, doi:10.5194/angeo-28-1157-2010, 2010.

Schneider, J., and Eixmann, R.: Three years of routine Raman lidar measurements of tropospheric aerosols: Backscattering, extinction, and residual layer height, Atmos. Chem. Phys., 2, 313-323, doi:10.5194/acp-2-313-2002, 2002.

Schwartz, S. E., Charlson, R. J., Kahn, R. A., Ogren, J. A., and Rodhe, H.: Why hasn't Earth warmed as much as expected?, J. Climate, 23, 2453-2464, 2010. 
Welton, E. J., Voss, K. J., Quinn, P. K., Flatau, P. J., Markowicz, K., Campbell, J. R., Spinhirne, J. D., Gordon, H. R., and Johnson, J. E.: Measurements of aerosol vertical profiles and optical properties during INDOEX 1999 using Micro-Pulse Lidars, J. Geophys. Res., 107, 8019, doi:10.1029/2000JD000038, 2002. 